\title{
Impact of Online Banking Adoption on Bank's Profitability: Evidence from Bangladesh
}

\author{
Sharul Islam, Mohammad Rokibul Kabir, Rabiul Hossain Dovash, Safa-E-Nafee, and Sovan Saha
}

\begin{abstract}
The rise in information technologies has transformed banking industry worldwide. To stay competitive, banks are introducing internet banking with the motive to achieve higher productivity and efficiency, reduce cost and increase profit. In Bangladesh, the impact of this new distribution channel in improving bank's performance is yet to be measured. It is against this backdrop this research is conducted to identify whether performance of banks that has adopted internet banking is different from banks yet to adopt internet banking. Furthermore, it is to be seen whether there is significant change in performance of banks before and after implementation of internet banking. Performance was measured through Return on Asset (ROA) and Return on Equity (ROE). Secondary data were collected from annual report of all the 30 listed banks in Bangladesh. The results revealed that ROA and $\mathrm{ROE}$ of banks with online banking is higher compared to banks without online bank. However, the results were insignificant. Furthermore, ROA and ROE were found out to be lower after implementation of internet banking and is statistically significant. Such findings could be attributed to the initial cost allocated for infrastructure development and fail to attract customer to adopt online banking in mass scale. Thus with investment done, the benefit could not be realized during the initial period of internet banking adoption.
\end{abstract}

Index Terms-Bangladesh; Internet Banking; Online Banking; ROA; ROE.

\section{INTRODUCTION}

The significance of the banking sector in any economy is paramount. Banks play a crucial role in developing the financial capacity of an economy. The rapid rise in globalization has blurred the geographical boundary of a country resulting in stiff competition in local markets. Foreign banks have started to make inroads into Bangladesh's economy, raising the necessity of local banks to become more competitive. Local commercial banks in Bangladesh, therefore, are taking measures to become more efficient in their overall operation and infrastructure.

To enhance the banking performance and to fascinate future customers, the conventional banking systems are changing to an elevated digital banking system. The banking sector is convinced that by embracing new technology, banks can become more responsive to customer demands,

Sharul Islam is with East Delta University, Chittagong, Bangladesh (email: sharul.i@eastdelta.edu.bd).

Mohammad Rokibul Kabir is with East Delta University, Chittagong, Bangladesh (e-mail: rokibul.k@eastdelta.edu.bd).

Rabiul Hossain Dovash is with East Delta University, Chittagong, Bangladesh (e-mail: rabiul@eastdelta.edu.bd

Safa-E-Nafee is a graduate from East Delta University, Chittagong, Bangladesh. (e-mail: safaenafee94@gmail.com).

Shovan Saha is a graduate from East Delta University, Chittagong, Bangladesh. (e-mail: antarsovan@gmail.com). resulting in customer centricity and overall customer satisfaction [1].

Online banking offers ease of access, secure transactions and 24-hour banking options. It ensures polished day-to-day operation framework of all banking transactions rather than lengthy monthly statements. Suspect of glitch or postponement can be easily recorded and resolved quicker. Automated routine bill payments, reducing the physical availability in bank premises as needed relative to banking hours may precede the time allotted in performing periodical banking activities. Internet banking delivers ease in the transaction and reduces banking cost. Therefore, the study is carried out to explain the impact that online banking has on bank's profitability.

In line with the slogan of Digital Bangladesh, the rapid improvement in IT has significantly influenced the banking industry in Bangladesh. Most of the banks are digitalized but digitalization in banking does not restrict to only online banking or mobile banking but also the execution of new technologies to transform the existing banking business module into a new banking business model. It is expected that such a model will itself assemble new customer base, demonstrate new financial services, ensure faster and seamless services to clients with minimal operational cost, zero error, easily adaptable and apparently, maximum security. The study here will help unveil what impact, if any, does online banking has on a bank's profitability.

Most of the studies on online banking in the current literature focus on the customer adoption of internet banking with few recent studies focused on the adoption of internet banking on bank's performance [2] - [4]. However, none of the previous literature focused on Bangladesh therefore, this study is undertaken to fill this gap and explain and compare the financial performances of the banks with and without online banking services in Bangladesh.

\section{LITERATURE REVIEW}

Online banking uses internet communication pathway to facilitate banking activities. Most common uses of online banking relate to fund transfer, ability to use the online medium to pay bills or mortgages, 24 hours access to savings or checking accounts to view balance and so forth [5]. Not only internet banking provides convenience to customers, but banks are also benefited through lower employee requirement and lower cost associated with less physical branches translating into an overall reduced cost of operation [6].

Numerous authors have used different performance metrics to identify the impact of internet banking on bank's performances, with ROE (return on equity) and ROA (return on asset) being the most common [7] - [10]. While a 
positive relationship is witnessed between introduction of internet banking and banks performance metrics [7], [9] [11], a time lag was observed suggesting that the impact of internet banking on the bank's performance cannot be judged using a single year study, instead it requires some duration of time before the benefit reflects on the key metrics [7].

Similarly, previous researchers have reported the positive impact of internet banking on firm's profitability, operating efficiency and financing activities suggesting that banks that have adopted internet banking have better performance indicator with lower cost [9]. Such finding was complemented with the work of [12] where it was reported that the adoption of internet banking reduces the overhead expenses of the banks and the cost reduction results increase in bank's profitability.

Reference [10] in their study intend to confirm whether banks that have adopted internet banking also has a positive relationship on the number of debit or credit cards issued as well as the number of ATMs installed by the banks. They concluded with a positive relationship suggesting that customers prefer convenience and adoption of internet banking can have a positive impact on ROA.

Demographic profile plays a vital role in terms of intention to adopt online banking suggesting that countries with more youth and well-educated population embraced internet banking. In such countries, adopting internet banking was linked to more profitability in comparison to traditional brick and mortar banks [13].

In contrary to the earlier work, [14] wanted to test whether internet adoption has an adverse effect on profitability at the beginning of the adoption year, and the positive impact on the deposit and credit branch. It was found out that embracing internet banking usually cut down the bank's profitability even though it improves deposit and loan growth.

The primary reason was that the market has its limit or ability, as in developing countries it is challenging to lure customers into adopting internet banking due to lower education and understanding about the benefit of adopting internet banking. In such cases, even though banks will expense in developing infrastructure for internet banking, the customer will be hesitant to switch, and thus the benefit that was promised with lower employee and branch cost will not be realized. Reference [12] observed an increase in physical branches for banks that adopted internet banking suggesting that internet banking is less of a substitute than a complement to traditional branches [13].

\section{HYPOTHESIS}

The existing literature has paved the way to conclude that banks adopting internet banking will be benefitted from cost reduction and higher profitability. Banks that have adopted internet banking can save cost by reducing the overall workforce and better utilization of the existing facilities [15]. This will result in higher efficiency and productivity and will, therefore, have a positive impact on profitability. Recent studies have confirmed a positive relationship between internet banking and financial performance as measured in terms of ROA and ROE [16], [17]. Furthermore, banks that have adopted internet banking have found to outperform in terms of profitability compared to banks yet to adopt internet banking [18], [19]. Thus it is expected that the implementation of internet banking will bring significant changes in the ROA and ROE compared to the pre-online banking era. Based on these, the following alternative hypotheses are proposed:

H1: There is a significant difference in ROA between banks with and without online banking

$\mathrm{H} 2$ : There is a significant difference in ROE between banks with and without online banking

H3: There is a significant change in ROA after the implementation of online banking services

$\mathrm{H} 4$ : There is a significant change in ROE after the implementation of online banking services

\section{METHODOLOGY}

\section{A. Sources of Data}

Secondary data were used for this study collected from the listed banks' annual reports and websites. Data of each bank consist of the year from 2007 to 2016. As the rapid expansion of e-banking started from 2011, data from 2007 to 2011 were considered as pre-online period, and data from 2012 to 2016 were considered as the post-online period.

\section{B. Variables of the Study}

The study was conducted to explain the effect of internet banking on banks' profitability particularly to examine whether the introduction of internet banking creates a positive or negative impact on banks' profitability. In order to measure the bank's profitability, two profitability ratios named ROA \& ROE were chosen as these two ratios are important measurement of profitability [7] - [10], [12].

\section{Population and Sample Size}

The population of the study consists of the listed banks in Bangladesh. As the population size consists of 30 listed banks, all the banks are taken as the sample for this research. Hence the sample size is 30 .

\section{Statistical Method}

This study tends to identify the difference between the performance of banks with online banking system and banks without online banking system. Therefore, the data gathered were grouped into two categories, banks with online features and banks without online features. Banks with online features referred to the banks having full-fledged online banking services while banks without online features referred to the banks having no or very few online banking features such as balance checking/statement viewing etc.

The data were used for t-test to achieve the results for identifying whether banks with full-fledged online banking system perform better than non-online banks. PairedSamples t-test has been conducted to find whether there is any significant change in banks' profitability after the implementation of online banking.

\section{RESULTS AND DISCUSSIONS}

To compare the profitability between the full-fledged online banks and non-online banking service proving banks, t-test was performed. From the t-test results related to ROA 
and ROE below (see table-1 and table-2 respectively) it is seen that the $\mathrm{t}$-stat values are 0.40929 and 0.1955 respectively which are less than the t-critical two-tailed value of 2.0484. Thus, the alternate hypotheses 1 and 2 are rejected confirming there is no significant difference in ROA and ROE between banks with and without online banking services. Although the mean ROA and ROE of online banks are higher than non-online banks, the results are statistically insignificant.

TABLE I: T-TEST FOR DIFFERENCE IN ROA BETWEEN BANKS WITH AND WITHOUT ONLINE BANKING

\begin{tabular}{|c|c|c|}
\hline t-test & $\begin{array}{l}\text { ROA } \\
\text { (Online } \\
\text { Banking) }\end{array}$ & $\begin{array}{l}\text { ROA } \\
\text { (Without } \\
\text { Online } \\
\text { Banking) }\end{array}$ \\
\hline Mean & 1.11844 & 0.94800222 \\
\hline Variance & 0.09326 & 2.5073692 \\
\hline t-stat & 0.40929 & \\
\hline $\begin{array}{l}\text { Table value at } 5 \% \\
\text { significance level }\end{array}$ & 2.04841 & \\
\hline
\end{tabular}

TABLE 2: T-TEST FOR DIFFERENCE IN ROE BETWEEN BANKS WITH AND WITHOUT ONLINE BANKING

\begin{tabular}{lll}
\multicolumn{2}{c}{ WITH AND WITHOUT ONLINE BANKING } \\
\hline \hline t-test & $\begin{array}{l}\text { ROE } \\
\text { (Online } \\
\text { Banking) }\end{array}$ & $\begin{array}{l}\text { (Without } \\
\text { Online } \\
\text { Banking) }\end{array}$ \\
\hline Mean & 13.358 & 13.162 \\
Variance & 8.48533 & 6.6457059 \\
t-stat & 0.1955 & \\
Table value at 5\% & 2.04841 & \\
significance level & & \\
\hline \hline
\end{tabular}

Paired sample t-test was conducted to evaluate the changes in ROA and after the implementation of online banking in full-fledged online banks. Table 3 and Table 4 below indicate that the mean ROA is lower (1.12) after the implementation of online banking than it was before the implementation (2.017). The difference is statistically significant at $5 \%$ level of significance. The reason for such changes might be the higher investments made by banks to avail internet banking system which increased the amount of assets significantly and it requires a few years to be recovered.

TABLE 3: PAIRED SAMPLE T-TEST STATISTICS FOR ROA

\begin{tabular}{|c|c|c|c|c|c|}
\hline \multicolumn{2}{|c|}{ Paired Samples Statistics } & Mean & $\mathrm{N}$ & Std. Deviation & $\begin{array}{l}\text { Std. Error } \\
\text { Mean }\end{array}$ \\
\hline \multirow[t]{2}{*}{ Pair 1} & $\begin{array}{l}\text { Average ROA of Banks } \\
\text { after introduction of } \\
\text { Online Banking }\end{array}$ & 1.1200 & 15 & .30620 & .07906 \\
\hline & $\begin{array}{l}\text { Average ROA of Banks } \\
\text { before introduction of } \\
\text { Online Banking }\end{array}$ & 2.0173 & 15 & .83241 & .21493 \\
\hline
\end{tabular}

TABLE 4: PAIRED SAMPLE T-TEST STATISTICS FOR ROA

\begin{tabular}{|c|c|c|c|c|c|c|c|}
\hline \multirow{2}{*}{\multicolumn{2}{|c|}{ Paired Samples Test }} & \multicolumn{3}{|c|}{ Paired Differences } & \multirow{2}{*}{ t } & \multirow{2}{*}{ df } & \multirow{2}{*}{ Sig. (2-tailed) } \\
\hline & & & & Std. Error & & & \\
\hline Pair 1 & $\begin{array}{l}\text { Average ROA of Banks } \\
\text { after introduction of } \\
\text { Online Banking - Average } \\
\text { ROA of Banks before } \\
\text { introduction of Online } \\
\text { Banking }\end{array}$ & -.89733 & .83380 & .21529 & -4.168 & 14 & .001 \\
\hline
\end{tabular}

Similarly, the paired sample t-test results show (Table 5 and Table 6) that the mean ROE is lower (13.16) after the implementation of online banking than it was before the implementation (21.98). The difference is also statistically significant at $5 \%$ level of significance.

TABLE 5: PAIRED SAMPLE T-TEST STATISTICS FOR ROE

\begin{tabular}{|c|c|c|c|c|c|}
\hline \multicolumn{2}{|c|}{ Paired Samples Statistics } & Mean & $\mathrm{N}$ & Std. Deviation & $\begin{array}{l}\text { Std. Error } \\
\text { Mean }\end{array}$ \\
\hline \multirow[t]{2}{*}{ Pair 1} & $\begin{array}{l}\text { Average ROE of Banks } \\
\text { after introduction of } \\
\text { Online Banking }\end{array}$ & 13.1633 & 15 & 2.91302 & .75214 \\
\hline & $\begin{array}{l}\text { Average ROE of Banks } \\
\text { before introduction of } \\
\text { Online Banking }\end{array}$ & 21.9800 & 15 & 7.45841 & 1.92575 \\
\hline
\end{tabular}

TABLE 6: PAIRED SAMPLE T-TEST STATISTICS FOR ROE

\begin{tabular}{|c|c|c|c|c|c|r|}
\hline \multirow{2}{*}{ Paired Samples Test } & \multicolumn{3}{|c|}{ Paired Differences } & & & \\
\cline { 2 - 7 } & Mean & Std. Deviation & $\begin{array}{c}\text { Std. Error } \\
\text { Mean }\end{array}$ & \multicolumn{1}{c|}{ d } & Sig. (2-tailed) \\
\hline Pair 1 $\begin{array}{l}\text { Average ROE of Banks } \\
\text { after introduction of } \\
\text { Online Banking - Average } \\
\text { ROE of Banks before } \\
\text { introduction of Online } \\
\text { Banking }\end{array}$ & -8.81667 & 8.53518 & 2.20377 & -4.001 & 14 & .001 \\
\hline
\end{tabular}

If we compare the results of the study with the earlier research findings, it would be tranquil to explain the findings of the study. Reference [7] reported that during the initial year after adopting internet banking there is no positive financial impact; it takes two or three years to reach an acceptable performance level. The outcome in this study shows relevancy where ROE has a positive result in the second year of adoption.

Similarly, previous studies reported that it takes considerable time to get acquainted to the e-banking services, as it takes two to three years to make satisfactory results after the launching of a new product [8]. Thus, the results of this study are at par with the findings of these previous studies. It would take at least three to four years to recoup their investment cost and make out benefit out of online banking system.

\section{RECOMMENDATIONS AND CONCLUSIONS}

This study concludes that non-online banks' average profitability is better but it might be due to the reason that the initial investment for facilitating online banking services needs a few years for recovery. The trend of profitability of online banks shows the improvement pattern. Moreover, with the increasing knowledge trend in the use of internet in Bangladesh, it is a matter of hope for online banks to become optimistic. The ease and benefits of using online banking will bring customers toward the adoption of such banking. In addition, online banking services are very effective in addressing lowering costs for banks and the customers, while high rate of accessibility by the users can be ensured.

Despite a good number of positive issues regarding online banking, security of transaction is still a matter of concern for many users and potential users of such banking services. Hence, banks need to address security concerns for mitigating online banking fraud. Review of Fraud Legislation could reduce fraud-related risks in banks.

To overcome customers' distrust on internet-based banking system, banks need to visibly demonstrate concern for security, reliability, and liability with realistic solutions to reduce or eliminate costs to customers in case of 
unsuccessful transactions or if processed inaccurately. Often, these are not purely technical issues, but rather, are related to process design, or, sometimes, partly to customer psychology and beliefs, which may or may not align with the actual technology and system. The Internet channel must be well integrated into other channels so that customers can easily interact with people who are trained to handle problems efficiently, and banks must adopt strong customer interface. Since adoption of ICT improves the banks' image and leads to a wider, faster and more efficient market, it is crucial for bank authority to escalate investment in ICT products to facilitate speed, convenience, and accurate services. The non-online banks are also recommended to convert into online banks for keeping pace with the ever-changing business world and the abovementioned issues must be addressed before the implementation of such banking system.

\section{REFERENCES}

[1] Hasan, A. S., Baten, M. A., Kamil, A. A., \& Parveen, S. (2010). Adoption of e-banking in Bangladesh: An exploratory study. African journal of business management, 4(13), 2718-2727.

[2] Akhisar, İ., Tunay, K. B., \& Tunay, N. (2015). The effects of innovations on bank performance: The case of electronic banking services. Procedia-Social and Behavioral Sciences, 195, 369-375.

[3] Stoica, Ovidiu, Seyed Mehdian, and Alina Sargu. "The impact of internet banking on the performance of Romanian banks: DEA and PCA approach." Procedia Economics and Finance 20 (2015): 610622.

[4] Kombe, S. K., \& Wafula, M. K. (2015). Effects of internet banking on the financial performance of commercial banks in Kenya a case of Kenya Commercial Bank. International Journal of Scientific and Research Publications, 5(5), 1-10.

[5] Hamid, M. R. A., Amin, H., Lada, S., \& Ahmad, N. (2007). A comparative analysis of Internet banking in Malaysia and Thailand. Journal of Internet Business, (4).

[6] Xue, M., Hitt, L. M., \& Chen, P. Y. (2011). Determinants and outcomes of internet banking adoption. Management Science, 57(2), 291-307.

[7] Onay, C., Ozsoz, E., \& Helvacioğlu, A. P. D. A. D. (2008, June). The impact of internet-banking on bank profitability-The case of Turkey. In 2008 Oxford Business \&Economics Conference Program.

[8] Khrawish, H. A., \& Al-Sa'di, N. M. (2011). The impact of e-banking on bank profitability: Evidence from Jordan. Middle Eastern Finance and Economics, 13, 142-158.

[9] Malhotra, P., \& Singh, B. (2009). The impact of internet banking on bank performance and risk: The Indian experience. Eurasian Journal of Business and Economics, 2(4), 43-62.

[10] Aduda, J., \& Kingoo, N. (2012). The relationship between electronic banking and financial performance among commercial banks in Kenya. Journal of Finance and Investment analysis, 1(3), 99-118.

[11] Arnaboldi, F., \& Claeys, P. (2008). Internet banking in Europe: a comparative analysis. Research Institute of Applied Economics, 8(11), $1-28$.

[12] Hernando, I., \& Nieto, M. J. (2007). Is the Internet delivery channel changing banks' performance? The case of Spanish banks. Journal of Banking \& Finance, 31(4), 1083-1099.

[13] DeYoung, R., Lang, W. W., \& Nolle, D. L. (2007). How the Internet affects output and performance at community banks. Journal of Banking \& Finance, 31(4), 1033-1060.
[14] Onay, C., \& Ozsoz, E. (2013). The impact of internet-banking on brick and mortar branches: the case of Turkey. Journal of Financial Services Research, 44(2), 187-204.

[15] Cheng, T. E., Lam, D. Y., \& Yeung, A. C. (2006). Adoption of internet banking: an empirical study in Hong Kong. Decision support systems, 42(3), 1558-1572.

[16] Sidhu, M. K. (2018). The impact of internet banking on bank performance: Empirical evidence from Indian Banks. Journal of Commerce \& Accounting Research, 7(2).

[17] Yang, S., Li, Z., Ma, Y., \& Chen, X. (2018). Does Electronic Banking Really Improve Bank Performance? Evidence in China. International Journal of Economics and Finance, 10(2), 82.

[18] Furst, K., Lang, W. W., \& Nolle, D. E. (2002). Internet banking. Journal of Financial Services Research, 22(1-2), 95-117.

[19] Hasan, I., Maccario, A., \& Zazzara, C. (2002). Do Internet activities add value? The Italian bank experience. RIETUMU BANK GROUP"(2003)“Consolidated and Bank Financial Statements and Auditor's Report for the year ended, 31 .

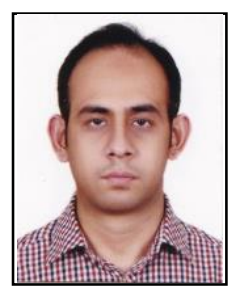

Sharul Islam was born in Dhaka, Bangladesh. He completed his Undergraduate degree in Business Administration from University of Technology Sydney in 2006, majoring in marketing and finance. He has also completed his MBA from Manchester Business School, UK.

$\mathrm{He}$ is currently working as a Lecturer and a MBA Coordinator at East Delta University, Chittagong, Bangladesh. His research interest is in Marketing and Strategic Management.

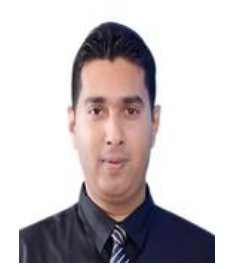

Mohammad Rokibul Kabir was born in Chittagong Bangladesh. He has been awarded PhD in 2017 by the University of Chittagong. Before that he completed his M.Phil, MBA and BBA from the same University. He has also passed LLB from the University of Information Technology and Sciences.

$\mathrm{He}$ is serving East Delta University as the Associate Professor in the School of Business Administration. He has around forty publications in different journals and he is highly interested in Accounting and Finance related research.

Dr. Kabir is leading the School of Business Administration of East Delta University as the Associate Dean. He is a member of Chittagong Bar Association, Bangladesh.

Business School, UK.

Rabiul Hossain Dovash was born in Chittagong, Bangladesh. He completed his Bachelor of Business Administration (BBA) from University of Madras in 2000. And then he completed MBA at North South University, Bangladesh in 2004 and Master of Management at University of Windsor, Canada in 2012. He is currently holding the position of a Lecturer in School of Business Administration of East Delta University.

Safa-E-Nafee is a Business Graduate of East Delta University. He has completed his Bachelor of Business Administration with a major in Finance in Spring 2018

Sovan Saha is a Business Graduate of East Delta University. He has completed his Bachelor of Business Administration with a major in Accounting in Spring 2018. 